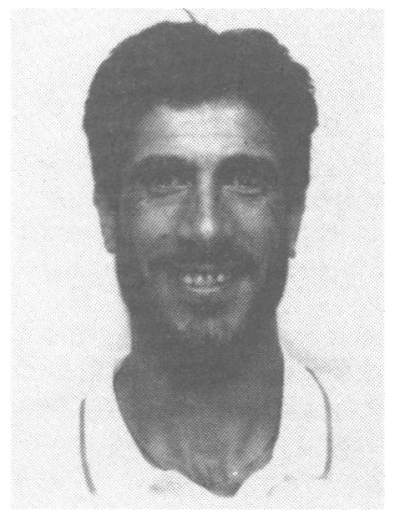

Y. Koutedakis

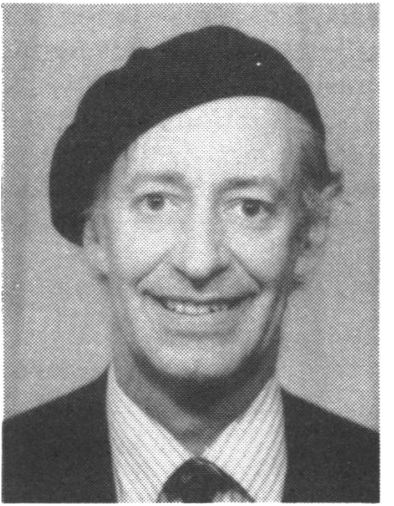

N. C. Craig Sharp

\title{
LACTIC ACID REMOVAL AND HEART RATE FREQUENCIES DURING RECOVERY AFTER STRENUOUS ROWING EXERCISE
}

\author{
Yiannis KOUTEDAKIS, BA, MA and N. C. CRAIG SHARP, BVMS, PhD, MRCVS
}

Human Motor Performance Laboratory, Dept. of P.E. and Sports Science, University of Birmingham, Birmingham B15 $2 T T$

\section{ABSTRACT}

Three tests were conducted to assess the effectiveness of three different intensities of exercise both in reducing blood lactic acid (LA) levels and in influencing subjects' heart rate (HR), following a $2000 \mathrm{~m}$ race in a rowing boat. In the first and second tests these variables were investigated during a 13 min recovery exercise at $60 \%$ and $40 \%$ of the preceding maximum rowing speed respectively. In the third test the subjects had a resting recovery.

The results include a significant increase $(P<0.001)$ in the rate of lactate removal following the $40 \%$ recovery compared with the $60 \%$ and resting recoveries. The HRs were significantly lower during the last minute of resting recovery compared with $40 \%$ and $60 \%$ recoveries $(P<0.001)$. The same was true when $40 \%$ recovery was compared with $60 \%$ recovery $(P<$ 0.001).

The present data suggest firstly that $40 \%$ of the maximum rowing speed is an appropriate pace for effective LA removal and secondly that, at least for trained rowers, $86 \%$ of their maximum HR can be taken as an indication of work of an intensity at or above anaerobic threshold.

Key words: Rowing, Anaerobic threshold, Lactic acid, Heart rates.

\section{INTRODUCTION}

The point at which blood lactate concentration begins to increase exponentially above resting values has been investigated regarding its relevance to exercise performance (Farrell et al, 1979; Rusko et al, 1980). When lactate accumulates to high levels in muscle and blood, it causes physical fatigue (Jacobs, 1981; Karlsson, 1980) and it is associated with a decrease in performance time of exhaustive exercise (Stamford et al, 1978). Therefore, the concept of the "anaerobic threshold" (AT) or the "lactate breaking point" has gained acceptance as a useful training aid (Jones and Ehrsam, 1982; Scheen et al, 1981).

Lactate which accumulates as a result of exercise, may be removed from the blood by the myocardium (Âstrand and Rodahl, 1977; Whereat and Orishimo, 1973), renal medulla (Yudkin and Cohen, 1974), brain (Nemoto et al, 1974) and liver (Rowell et al, 1966) but mainly by skeletal muscles (Davies et al, 1970; Hermansen and Stensvold, 1972; McGrail et al, 1978). However, when exercise is performed after blood lactate has been elevated, there is an increased lactate uptake (Belcastro and Bonen, 1975; Bonen and Belcastro, 1976; Evans and Cureton, 1983; Stamford et al, 1981; Weltman et al, 1979). Intensity of recovery exercise (Hermansen and Stensvold, 1972; Sharp, 1982), type of exercise (Belcastro and Bonen, 1975; Bonen and Belcastro, 1976), training status (Andersen and Henriksson, 1977), and type of muscle fibre (Bonen et al, 1978; Lamb, 1978), are thought to influence blood lactate removal.
Rowing is considered to be one of the most physically demanding sports (Hagerman et al, 1978; Secher, 1983) as rowers work near their maximal $\mathrm{VO}_{2}$ (Hagerman, 1984; McKenzie and Rhodes, 1982) for 6-8 mins by recruiting a very large muscle mass and deriving their energy needs from both aerobic and anaerobic metabolism (Hagerman et al, 1978).

However, unlike distance runners, who are usually careful not to exceed the anerobic threshold (AT) in the early stages of the race, rowers quickly achieve extremely high energy expenditures, and therefore induce high lactate levels very early in the race (Hagerman et al, 1978; Hagerman et al, 1979). Thus the removal of lactic acid (LA) is of great interest in rowing.

Although many investigators have worked on athletes' recovery in a variety of sports, very little work exists which is directly relevant to rowers and rowing. Nevertheless, it would be very useful if rowing coaches could control their athletes' recovery by using two inexpensive and widely available measures, boat speed and HR. The purpose of this study, therefore, was to determine the most appropriate rowing speed for LA removal and its influence on subjects' $H R$, after a $2000 \mathrm{~m}$ race.

\section{METHODS Subjects}

Seven healthy club rowers and scullers volunteered as sub- 
jects. They were members of four different rowing clubs each with, at least, five years of rowing experience. They were in excellent physical condition when studied, preparing for various regattas. All of them competed in either coxed pairs or single sculls. The subjects were randomly tested three times each. Anthropometric data for the subjects appear in Table I.

TABLE I

Physical characteristics of the subjects

\begin{tabular}{|c|c|c|c|c|c|c|}
\hline & Subjects & $\begin{array}{l}\text { Age } \\
\text { yrs }\end{array}$ & $\begin{array}{l}\text { Height } \\
\text { cm }\end{array}$ & $\begin{array}{c}\text { Weight } \\
\text { kg }\end{array}$ & $\%$ Body fat & $\begin{array}{l}\text { L.B.M. } \\
\text { kg }\end{array}$ \\
\hline 1st & AN & 21 & 189.4 & 84.4 & 14.4 & 72.25 \\
\hline crew & BC & 20 & 186.1 & 83.2 & 13.4 & 72.06 \\
\hline 2nd & NG & 23 & 181.3 & 76.4 & 11.8 & 67.39 \\
\hline crew & $\mathbf{F F}$ & 23 & 187.8 & 85.1 & 13.8 & 73.36 \\
\hline $\begin{array}{l}\text { 3rd } \\
\text { Crew }\end{array}$ & DN & 23 & 182.5 & 79.6 & 14.5 & 68.06 \\
\hline $\begin{array}{l}\text { 4th } \\
\text { Crew }\end{array}$ & JK & 24 & 179.4 & 77.3 & 13.1 & 67.18 \\
\hline $\begin{array}{l}\text { 5th } \\
\text { Crew }\end{array}$ & JM & 25 & 190.1 & 83.5 & 15.3 & 70.73 \\
\hline Range & & $20-25$ & 179.4-190.1 & $76.4-85.1$ & $11.8-15.3$ & 67.18-73.36 \\
\hline$\overline{\mathbf{x}}$ & & 22.71 & 185.22 & 81.35 & 13.75 & 70.14 \\
\hline S.D. $n-1$ & - & 1.70 & 4.19 & 3.54 & 1.13 & 2.56 \\
\hline
\end{tabular}

\section{First Test}

At the completion of warm-up, the subjects performed a $2000 \mathrm{~m}$ race to exhaustion. Immediately afterwards they were asked to row the same distance $(2000 \mathrm{~m})$ at $60 \%$ of their maximum speed, by reducing stroke rate from $\mathbf{3 8}$ to $22 / \mathrm{min}$. During this "active recovery", three capillary blood samples were taken from each subject at the 1st, 5th and 13th minute by $Y K$, following in a power boat which drew alongside. The samples were deproteinised and then placed in an ice box for temporary storage. Blood lactic acid concentrations were measured following the Lactate Dehydrogenase and NAD method using the Boehringer Mannheim Diagnostic kit. The subjects' HRs were recorded every 30 seconds and simultaneously every $250 \mathrm{~m}$ of rowing using the Hewlett Packard telemetry system.

\section{Second Test}

This test took place at the same time of day, four to five days later, using the same boats, oars and subjects. The same procedure as above was followed here, the only difference being that the athletes were asked to "recover" at $40 \%$ of their maximum rowing speed.

\section{Third Test}

This was administered four to six days after the second test and the rowers were given a passive recovery after the end of the races. The number of blood samples and the overall procedure were identical to the other tests.

The statistical analyses performed were the paired t-tests for the last minute of the three different recoveries and referred to both LA and HR relative $(\%)$ values. Differences of $P<0.05$ were considered significant.

\section{RESULTS}

Blood LA concentrations (mmol.1-1) and HRs (beats.min-1) were expressed relative to the post-exercise values $(100 \%)$, Tables II, III).

TABLE III

Mean LA concentrations (mmol.1-1), KRs (beats.min-1) and their relative (\%) values for the first and thirteenth minute of recovery*

\begin{tabular}{|c|c|c|c|c|}
\hline & \multicolumn{4}{|c|}{ Recovery } \\
\hline & \multicolumn{2}{|c|}{ Lactic Acid } & \multicolumn{2}{|c|}{ Heart Rate } \\
\hline & 1st min & 13th $\mathrm{min}$ & 1st min & 13th min \\
\hline \multirow[t]{2}{*}{ First Test } & 12.22 & 7.78 & 196.71 & 169.14 \\
\hline & 1.09 & 1.38 & 7.47 & 3.33 \\
\hline \multirow[t]{2}{*}{ (60\% of max rowing speed) } & 100 & 64.37 & 100 & $86.08^{\circ}$ \\
\hline & & 14.34 & & 3.54 \\
\hline \multirow[t]{2}{*}{ Second Test } & 12.47 & 6.08 & 199.28 & 138 \\
\hline & 0.96 & 1.07 & 8.03 & 4.61 \\
\hline \multirow[t]{2}{*}{ ( $40 \%$ of max rowing speed) } & 100 & 48.72 & 100 & $69.35^{\circ}$ \\
\hline & & 6.67 & & 4.15 \\
\hline \multirow[t]{2}{*}{ Third Test } & 12.61 & 8.05 & 196.42 & 87.23 \\
\hline & 0.94 & 0.96 & 7.16 & 7.88 \\
\hline \multirow[t]{2}{*}{ (Resting recovery) } & 100 & 63.84 & 100 & 44.28ः \\
\hline & & 6.39 & & 2.94 \\
\hline
\end{tabular}

* $N=\bar{X}$, S.D. $n-1$

- significantly different, $P<0.001$

The LA removal rates during the $40 \%$ recovery period were significantly faster than during the resting and $60 \%$ recoveries ( $p<0.001$ ). Blood LA concentrations were reduced to $48.7 \%$ of the initial post-exercise samples within 13 minutes during the $40 \%$ recovery. The corresponding values for the resting and $60 \%$ recoveries were $63.8 \%$ and $64.4 \%$ respectively.

TABLE \|

Indhidual relative LA concentrations and $H$

\begin{tabular}{|c|c|c|c|c|c|c|c|c|c|c|}
\hline & \multirow[b]{2}{*}{ Subjects } & \multicolumn{3}{|c|}{$60 \%$ recovery } & \multicolumn{3}{|c|}{$40 \%$ recovery } & \multicolumn{2}{|c|}{ Resting recovery } & \multirow[b]{2}{*}{$\begin{array}{c}\text { HR } \\
\text { \% post race }\end{array}$} \\
\hline & & $\underset{\% \text { post race }}{\text { LA }}$ & & $\begin{array}{c}\text { HR } \\
\% \text { post race }\end{array}$ & $\underset{\% \text { post race }}{\text { LA }}$ & & $\begin{array}{c}\text { HR } \\
\text { \% post race }\end{array}$ & $\underset{\% \text { post race }}{\text { LA }}$ & & \\
\hline \multirow{2}{*}{$\begin{array}{l}\text { First crew } \\
(2+)\end{array}$} & AN & 87.87 & 1 & 83.9 & 54.09 & 1 & 71.13 & 73.58 & 1 & 45.95 \\
\hline & BC & 62.23 & 1 & 89.23 & 39.13 & 1 & 66.32 & 61.32 & & 47.14 \\
\hline \multirow{2}{*}{$\begin{array}{l}\text { Second crew } \\
(2+)\end{array}$} & NG & 68.81 & 1 & 83.33 & 57.75 & 1 & 65.07 & 66.42 & 1 & 43.5 \\
\hline & $\mathbf{F F}$ & 50.60 & 1 & 88.94 & 45.43 & 1 & 66.82 & 56.20 & 1 & 44.44 \\
\hline $\begin{array}{l}\text { Third crew } \\
\text { (IX) }\end{array}$ & DN & 43.63 & 1 & 80.28 & 42.82 & 1 & 77.12 & 64.30 & 1 & 42.26 \\
\hline $\begin{array}{l}\text { Fourth crew } \\
\text { (IX) }\end{array}$ & JK & 68.56 & 1 & 88.29 & 53.14 & 1 & 71.28 & 68.66 & 1 & 47.93 \\
\hline \multirow[t]{4}{*}{$\begin{array}{l}\text { Fifth crew } \\
\text { (IX) }\end{array}$} & JM & 68.90 & 1 & 88.60 & 48.67 & 1 & 67.78 & 56.37 & 1 & 39.47 \\
\hline & Range & $43.63-87.87$ & 1 & $80.28-89.23$ & $39.13-57.75$ & I & 65.07-77.12 & $56.20-73.58$ & 1 & $39.47-47.93$ \\
\hline & $\overline{\mathbf{x}}$ & 64.37 & 1 & 86.08 & 48.72 & I & 69.36 & 63.84 & I & 44.38 \\
\hline & $S D_{n-1}$ & 14.34 & I & 3.54 & 6.67 & 1 & 4.15 & 6.39 & 1 & 2.94 \\
\hline
\end{tabular}




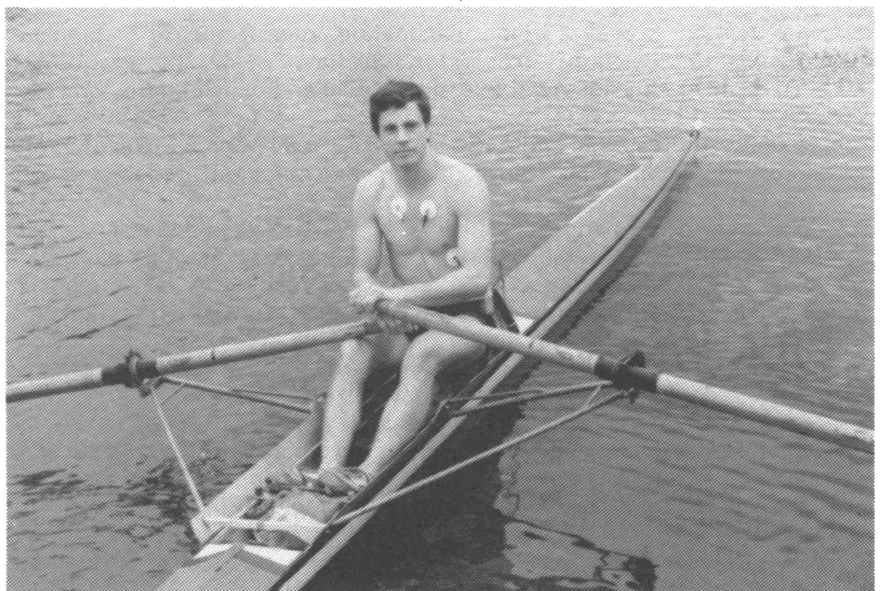

The HRs were also significantly lower during the last minute of the $40 \%$ recovery compared to the $60 \%$ recovery ( $p<0.001)$. The same was true when resting recovery was compared to $40 \%$ and $60 \%$ recovery ( $p<0.001$ ). In the final minute (13th) of the three different recoveries the mean HR levels were reduced to $86.1 \%, 69.4 \%$, and $44.4 \%$ for the $60 \%$, $40 \%$ and rest recovery, relative to their immediate postexercise HR values (Table III).

\section{DISCUSSION}

\section{Lactic Acid Removal}

The removal of LA from muscle and blood following strenuous physical activity is an integral part of the recovery process. There is good agreement that, within limits (Boileau et al, 1983), an active recovery promotes the removal of blood lactate better than a resting recovery (Belcastro and Bonen, 1975; Bonen and Belcastro,m 1976; Evans and Cureton, 1983; Hermansen and Stensvold, 1972; Stamford et al, 1981; Weltman et al, 1979). This effect can be attributed to the greater turnover and metabolic clearance rate of LA during moderate exercise (Issekutz et al, 1976). The results of the present study reinforce previous work on other sports, suggesting that the rate of LA removal from the blood is augmented during active recovery compared with passive recovery. This is particularly the case when the $40 \%$ and passive recoveries were compared (Table III).

In the present study the results obtained from the $40 \%$ recovery were similar to those of Bonen and Belcastro (1976). They found that "blood LA concentrations were reduced to $50 \%$ of the initial post-exercise samples within 10 mins during the free-jogging recovery", while in the present study, LA was reduced to $49 \%$ within 13 mins, during the $40 \%$ recovery. In contrast, the remaining blood LA during the $60 \%$ recovery was $64 \%$ of the initial postexercise samples.

Previous studies have shown that the rate of blood lactate removal increases with increased intensity of active recovery up to approximately $40 \%$ of $\mathrm{VO}_{2}$ max (Belcastro and Bonen, 1975; Hermansen and Stensvold, 1972). Moreover, it has been observed that LA removal during active recovery is less effective at intensities above AT than below the threshold (Davies et al, 1970; Weltman et al, 1979). This is because the rate of LA production exceeds the rate of LA reduction. Indeed, at exercise intensities above the AT, not only is LA produced in greater quantity but it may be that certain removal sites become relatively ineffective in removing LA due in part to reduced blood flow (Boileau et al, 1983). Rowell et al (1966) have demonstrated reduced hepatic and splanchnic blood flow as exercise intensity increases. It could be said, therefore, that the $60 \%$ recovery used in the present study probably provided an exercise intensity at or above the AT given that firstly, LA concentration at the 13th minute of this recovery was significantly higher compared to $40 \%$ recovery and secondly, in agreement with other research (Stamford et al, 1981), there was no difference between the $60 \%$ and resting recovery values at the same time (Table III).

\section{Heart Rates}

To direct and evaluate training, knowledge of HR at AT could prove to be a valuable aid to both coaches and oarsmen. This is because there is a greater degree of improvement in AT when working at AT intensities, than at those above or below it (Gibbons et al, 1983; Sjodin et al, 1982). Additionally, the different seasonal emphasis on developing rowers' aerobic and anaerobic capacities, illustrates the potential usefulness of HR at AT.

The results of the present study show that the mean HR value at the 13 th minute of the $60 \%$ recovery was $86 \%$ of the maximum HRs. This value is similar to findings of Parkhouse et al (1982), Dressendorfer et al (1981) and Dwyer and Bybee (1983) who observed that HRs at AT expressed as a percentage of maximal cardiac frequency were 84,86 , 88 and $86.3 \%$ for trained, highly trained, normal males and normal women respectively. Other investigators, using rowing ergometers, found that the mean HR values at AT were 167 and 168 beats. in $^{-1}$ for international and national rowers (Mahler et al, 1984; Mickelson and Hagerman, 1982). These HRs, however, are very close to the mean value (169.14 beats.min-1 (Table III)) found in the present study corresponding to the last minute of the $60 \%$ recovery. Finally, Tables II and III show that less LA was removed during the $60 \%$ recovery compared to resting recovery. It could be said, therefore, that during the $60 \%$ recovery the subjects used for this study worked at or above their AT; also, $86 \%$ of their maximum HR could be taken as an indication of work intensity at or above their threshold.

TABLE IV

Racing times achieved, the calculated recovery times and the speed during recovery for all crews

\begin{tabular}{|c|c|c|c|c|c|c|c|}
\hline Exercise & $\begin{array}{l}\text { 1st } \\
\text { crew } \\
(2+)\end{array}$ & $\begin{array}{l}\text { 2nd } \\
\text { crew } \\
(2+)\end{array}$ & $\begin{array}{c}\text { 3rd } \\
\text { crew } \\
\text { (IX) }\end{array}$ & $\begin{array}{l}\text { 4th } \\
\text { crew } \\
\text { (IX) }\end{array}$ & $\begin{array}{l}\text { 5th } \\
\text { crew } \\
\text { (IX) }\end{array}$ & $\bar{X} / S . D \cdot n-1$ & \\
\hline $\begin{array}{l}\text { Race } \\
\text { (min) }\end{array}$ & 7.25 & 7.28 & 7.46 & 7.55 & 7.54 & $7.41 / 0.14$ & \multirow{3}{*}{$\begin{array}{l}\text { First Test } \\
(60 \% \text { of } \max \\
\text { speed) }\end{array}$} \\
\hline $\begin{array}{l}\text { Recovery } \\
\text { (min) }\end{array}$ & 12.08 & 12.13 & 12.43 & 12.58 & 12.56 & $12.35 / 0.23$ & \\
\hline $\begin{array}{l}\text { Speed of recovery } \\
\text { (metres.min-1) }\end{array}$ & 165.5 & 164.8 & 160.9 & 158.9 & 159.2 & $161.86 / 3.1$ & \\
\hline $\begin{array}{l}\text { Race } \\
\text { (min) }\end{array}$ & 7.28 & 7.30 & 7.20 & 7.58 & 8.01 & $7.47 / 0.33$ & \multirow{3}{*}{$\begin{array}{l}\text { Second Test } \\
\text { (40\% of max } \\
\text { speed) }\end{array}$} \\
\hline $\begin{array}{l}\text { Recovery } \\
\%(\min )\end{array}$ & 18.20 & 18.25 & 18.00 & 19.34 & 20.02 & $18.76 / 0.87$ & \\
\hline $\begin{array}{l}\text { Speed of recovery } \\
\text { (metres.min-1) }\end{array}$ & 109.8 & 109.5 & 111.1 & 103.4 & 99.9 & $106.74 / 4.84$ & \\
\hline $\begin{array}{l}\text { Race } \\
(\min )\end{array}$ & 7.20 & 7.22 & 8.00 & 7.44 & 7.34 & $7.44 / 0.32$ & \multirow{3}{*}{$\begin{array}{l}\text { Third Test } \\
\text { (Resting } \\
\text { recovery) }\end{array}$} \\
\hline $\begin{array}{l}\text { Recovery } \\
\text { (min) }\end{array}$ & - & - & - & - & - & - & \\
\hline $\begin{array}{l}\text { Speed of recovery } \\
\text { (metres.min-1) }\end{array}$ & - & - & - & - & - & - & \\
\hline
\end{tabular}

Lactate clearing regimes, such as described above are becoming increasingly important in the development of anaerobic power through strenuous interval training. In this context it is interesting to note that comparative "clearance" speeds for other sports investigated in the authors' laboratory are of the order of $50 \%$ for cycling, $60 \%$ for sprint canoeing and $65 \%$ for running. 


\section{References}

Andersen, P. and Henriksson, J., 1977 "Capillary supply of the quadriceps femoris muscle of man: adaptive response to exercise". J.Physiol. 270: 677-690.

Astrand, P.-O. and Rodahl, K., 1977. Textbook of Work Physiology. McGrawHill Book Co., NY, pp. 312-313.

Belcastro, A. N. and Bonen, A., 1975 "Lactic acid removal rates during controlled and uncontrolled recovery exercise". J.Appl.Physiol. 39: 392-396.

Boileau, R. A., Misner, J. E., Dykstra, G. L. and Spitzer, T. A., 1983 "Blood lactic acid removal during treadmill and bicycle exercise at various intensities". J.Sports Med. 23: 159-167.

Bonen, A. and Belcastro, A. N., 1967 "Comparison of self-selected recovery methods on lactic acid removal rates". Med.Sci.Sports 8: 176-178.

Bonen, A., Campbell, C. J., Kirby, R. L. and Belcastro, A. N., 1978 "Relationship between slow-twitch muscle fibers and lactic acid removal". Can.J. Appl.Sport Sci. 3: 160-162.

Davies, C. T. M., Knibbs, A. V. and Musgrove, L., 1970 "The rate of lactic acid removal in relation to different baselines of recovery exercise". Int.Z. Angew.Phys. 28: 155-161.

Dressendorfer, R. H., Smith, J. L., Merrill, J., Catlin, M. J. et al, 1981 "Quantification of exercise responses at $A T$ in healthy men: relation to prescribed training HRs" (Abstract). Med.Sci.Sports 13: 79.

Dwyer, J. and Bybee, R., 1983 "Heart rate indices of the anaerobic threshold". Med.Sci.Sports 15: 72-76.

Evans, W. and Cureton, K. J., 1983 "Effect of physical conditioning on blood lactate disappearance after supramaximal exercise". Brit.J.Sports Med. 17: 40-45.

Farrell, P. A., Wilmore, J., Coyle, E., Billing, J. and Costill, D., 1979 "Plasma lactate accumulation and distance running performance". Med.Sci.Sports 11: $338-344$.

Gibbons, S. E., Jessup, T. G., Wells, D. T. and Werthmann, D. A., 1983 "Effects of various training intensity levels on AT and aerobic capacity in females". J.Sports Med.\& Phys. Fitness 23: 315-318.

Hagerman, F. C., 1984 "Applied physiology of rowing". Sports Med. 1: 303-326.

Hagerman, F. C., Hagerman, F. R. and Mickelson, T. C., 1979 "Physiological profiles of elite rowers". Physician Sportsmed. 7: 74-83.

Hagerman, F. C., Connors, M. C., Gault, J. A. et al, 1978 "Energy expenditure during simulated rowing". J.Appl.Phys. 45: 87-93.

Hermansen, L. and Stensvold, 1.,1972 “Production and removal of lactate during exercise in man". Acta Phys.Scand. 86: 191-201.

lssekutz, B., Shaw, W. A. S. and Issekutz, A. C., 1976 "Lactate metabolism in resting and exercising dogs". J.Appl.Phys. 40: 312-319.

Jacobs, I., 1981 "Lactate, muscle glycogen and exercise performance in man". Acta Phys.Scand., Suppl.: 495.

Jones, N. and Ehrsam, R., 1982 "The anaerobic threshold". Exerc.Sports Sci. Rev. 10: 49-83.
Karlsson, J., 1980 "Localised muscular fatigue: role of muscle metaboism and substrate depletion". Exerc.Sports Sci.Rev. 7: 1-42.

Lamb, D. R., 1978. Physiology of Exercise. McMillan Publishing Co. Inc., NY: p. 46.

Mahler, D. A., Andrea, B. E. and Andresen, D. A., 1984 "Comparison of 6-min 'all-out' and incremental exercise tests in elite oarsmen". Med.Sci.Sports Exerc. 16: 567-571.

McGrail, J., Bonen, A. and Belcastro, A. N., 1978 "Dependence of lactate removal on muscle metabolism in man". Eur.J.Appl.Phys. 39: 89-97.

McKenzie, D. C. and Rhodes, E. C., 1982 "Cardiorespiratory and metabolic responses to exercise on a rowing ergometer". Auist.J.Sports Med. 14: 21-23.

Mickelson, T. C. and Hagerman, F. C., 1982 "Anaerobic threshold measurements of elite oarsmen". Med.Sci.Sports Exerc. 14: 440-444.

Nemoto, E. M., Hoff, J. T. and Servinghans, J. W., 1974 "Lactate uptake by brain during hyperlactateamia and hypoglycemia". Stroke 5: 48-53.

Parkhouse, W. S., McKenzie, D. C., Rhodes, E. C., Dunwoody, D. and Wiley, P. 1982 "Cardiac frequency and anaerobic threshold". Eur.J.Appl.Phys. 50: 117-123.

Rowell, L.B., Kraning, K. K. et al, 1966 "Splanchnic removal of lactate and pyruvate during prolonged exercise in man". J.Appl.Phys. 27: 1773-1783.

Rusko, H., Rahkila, P. and Karvinen, E., 1980 "Anaerobic threshold, skeletal muscle enzymes and fibre composition in young female cross-country skiers": Acta Phys.Scand. 108: 263-268.

Scheen, A., Juchmes, J. and Cession-Fossion, A., 1981 "Critical analysis of the 'Anaerobic Threshold' during exercise at constant work loads". Eur.J. Appl.Phys. 46: 367-377.

Secher, N. H., 1983 "The physiology of rowing". J.Sports Sci. 1: 23-53.

Sharp, N. C. C., 1982 "Muscle: the inside story". Running Magaz., November, p. 37.

Sjodin, B., Jacobs, I. and Svedenbag, J., 1982 "Changes in onset of blood lactate accumulation (OBLA) and muscle enzymes after training at OBLA" Eur.J.Appl.Physiol. 49: 45-57.

Stamford, B. A., Rowland, R. and Maffatt, R. J., 1978 "Effect of severe prior exercise on assessment of maximal $\mathrm{O}_{2}$ uptake". J.Appl.Phys. 44: 559-563.

Stamford, B. A., Weltman, B. A., Moffatt, R. J. and Sady, S., 1981 "Exercise recovery above and below anaerobic threshold following maximal work" J.Appl.Phys. 51: 840-844.

Weltman, A., Stamford, B. A. and Fulco, C., 1979 "Recovery from maxima effort exercise: lactate disappearance and subsequent performance". J.Appl.Physiol. 47: 677-682.

Whereat, A. F. and Orishimo, M. W., 1973 "Regulation of the rate of lactic acid oxidation by the heart". Recent Advanced Studies in Cardiac Structure Metabolism 3: 31-38.

Yudkin, J. and Cohen, R. D., 1974 "The contribution of the kidney to remova of a lactic acid load under normal and acidotic conditions in the conscious rat". Clin.Sci.Mol.Med. 46: 8P.

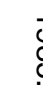

\section{.}

